\title{
Working Away From Home
}

\section{The First Installment}

TRAVEL, THEY SAY, broadens the mind. Whoever "they" are probably hasn't passed through an international airport in recent years where travel just leads to a numbing of the grey cells. That said, more students are traveling far afield as a part of their studies than ever before. In the 1970s (OK, my day), the most exciting journey as an undergraduate was to the library. Now, there are myriad options for oceanography students to study abroad as a part of their courses, or to undertake vocational work during the long summers. Their own journeys to the library are now less frequent due to online journals and texts.

When I first sat down to write this "short" article, it was so vast it filled several (electronic) waste bins. Thus, in this first of a two-part serial (you need to keep subscribing to see how it finishes), we will look at undergraduates and vacation work, leaving the more complex issue of "year abroad" study until my

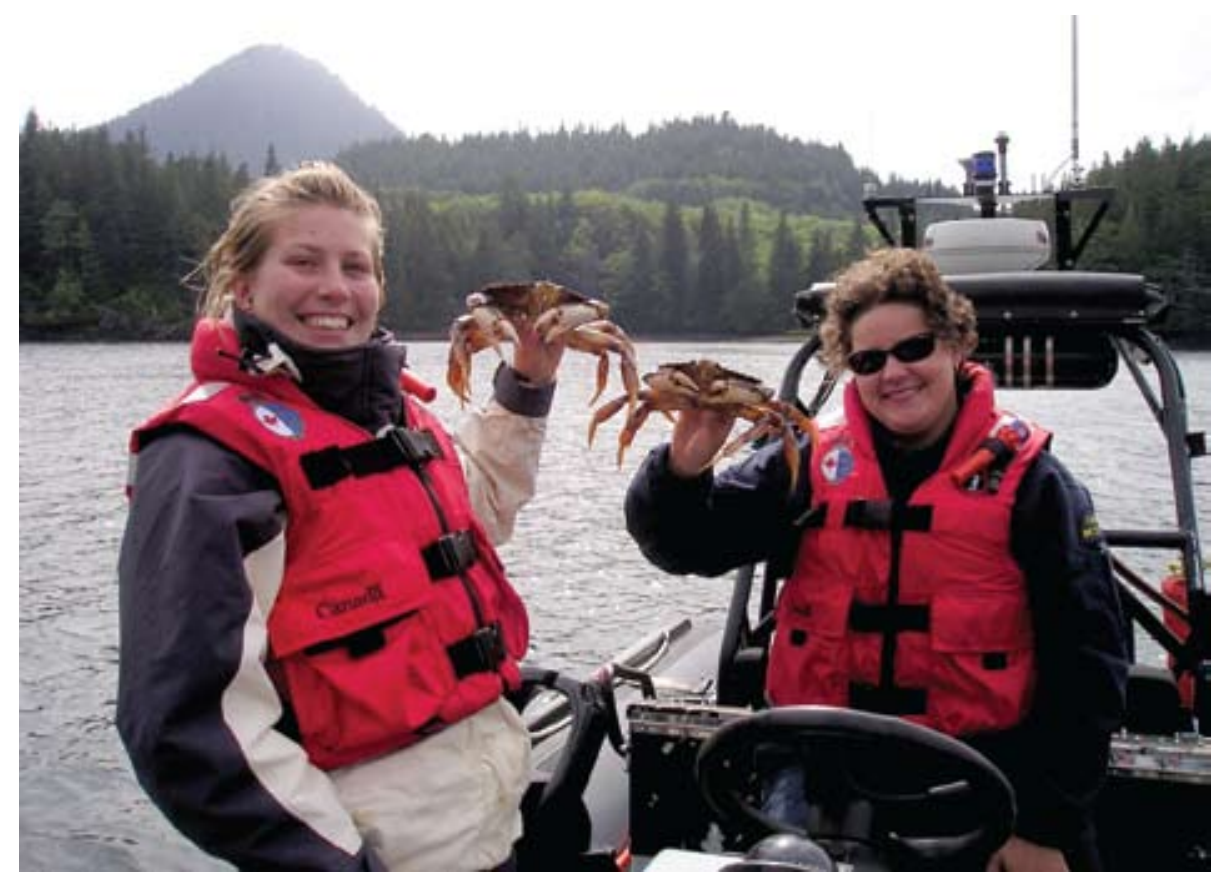

Figure 1. Southampton student working with a Canadian researcher in Vancouver Sound, tagging crabs. next dispatch in the summer.

Of the large numbers of students of oceanography, marine biology, and related subjects at the University of Southampton, I guess that about 40 will spend their summers working in jobs related to their subjects. This work varies immensely from commercial surveys in regional waters, to employment at oceanographic organizations around the world. This traffic of developing young scientists is two-way, and most academic departments encourage this extension of learning. But, how easy is it to find placements and how fair is the distribution?

I am often asked (usually by parents) why we don't provide such placements as a part of the course. The reasons are simple: (1) you try finding a couple of hundred placements every year, and (2) although most of our students are hard working and bright (no, really, they are), there are a select few who I wouldn't want to impose on anyone. Students who initiate the placement search are more likely to be keen and enthusiastic to follow it through, albeit with a helping hand from their academic supervisors. With a few exceptions, I would also propose that most students are not equipped for placement until they are 
at least two years into their degrees, not just academically but also in terms of transferable skills.

Placements come in two flavorspaid and unpaid - and this is where the unfairness can sometimes creep in. As a rule of thumb, the more exotic the work or location, the less likely it is to pay. This situation may arise because certain projects, like Coral Cay Conservation or Loggerhead Turtle Watch, charge students to participate, and these costs can be high-often several thousand dollars for a few weeks' "work." Although these programs may be legitimate, many schemes are just tourism by another name, and the learning experience can be very limited.

Many government institutes and companies abroad are unable to pay students if they do not have the correct work visas. We have students who regularly undertake placements in Canada, the United States, and Australia. To get a work visa for a summer is not feasible and so a student needs to be selfsupporting. This arrangement doesn't just mean accommodation and food, but also getting there. A well-off student may not be burdened by this situation, but for others, not only is this a cost they can ill afford, but they are then not earning money over the summer to support themselves during regular term studies.

For many years, my department has been lucky to have a fantastic contact at the Canadian Institute of Oceanographic Sciences (IOS) in Pat Bay, who has arranged placements for four or five students every year. These students' experiences have been unbelievable, including participation in several research cruises to the Arctic, geophysical surveys in the Vancouver Island region, and cetacean

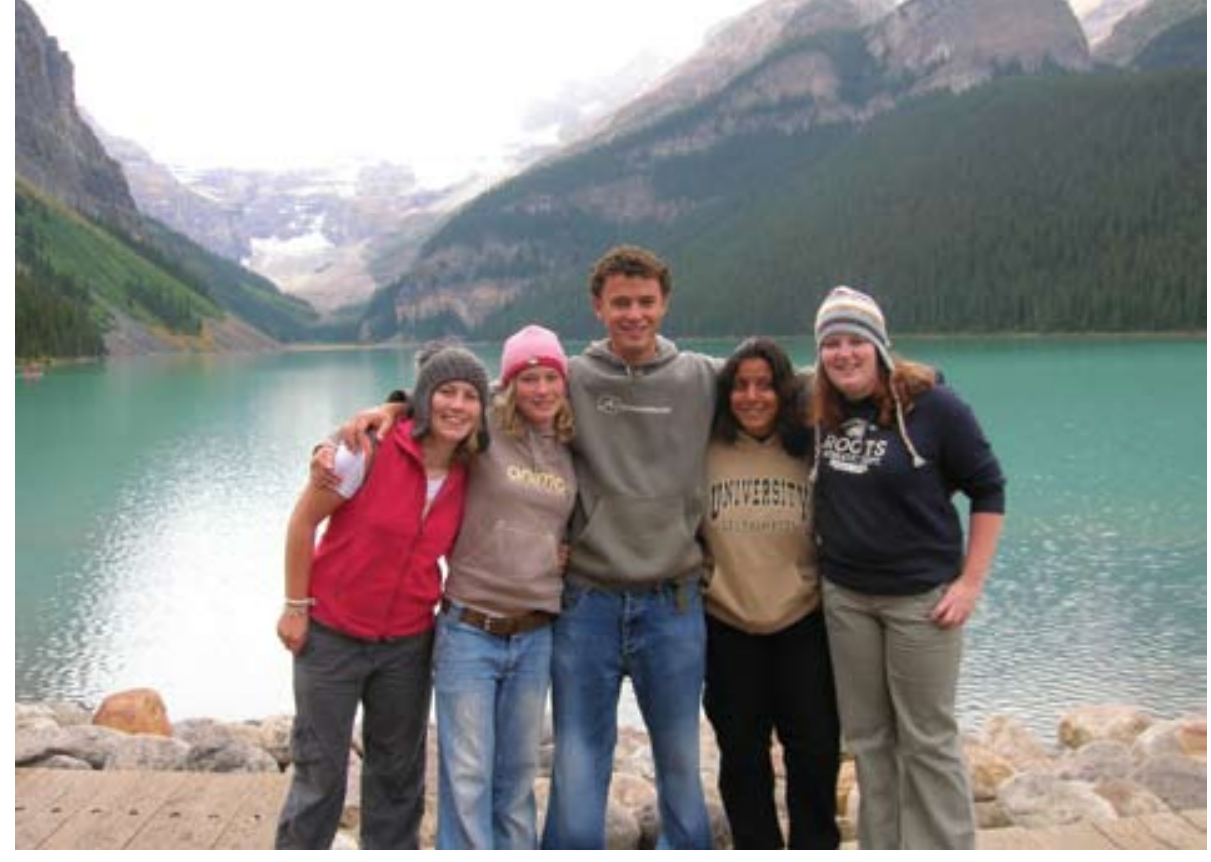

Figure 2. Vancouver Island summer students get time off to enjoy the scenery.

surveys in the field during migration season. Students are an active part of research teams, and they contribute to them during a period when many institute staff are on vacation. Without exception, students return from this experience and other work abroad with renewed enthusiasm, and we see an increase in their degree marks in their final years. In two instances, IOS staff members were so impressed they took the students on for postgraduate research after they graduated.

The cost? Much depends on what can be arranged locally in terms of support. One year, a member of the IOS staff went on extended vacation and let our four visiting students house-sit for them, leaving not only the house but also a pickup truck for the students to use in return for cat and goldfish duties. I'm not sure how wise that was, but I'm glad to say neither the cats nor the students ate the goldfish, and the pickup was left clean and dent free. Over the years, the price of such trips ranges from US\$2,000-3,000 at today's prices. Some of this cost can be met from bursaries from the home university, and some travel funds from corporate trusts can be sought. However, in the current economic climate, such sources are rapidly drying up and most of the cost has had to come from the students' own resources.

Increasing financial constraints then lead us to explore the paid variety of employment. By its nature, it will tend to be back in the students' own country, though foreign travel is by no means ruled out. Traditionally, this employment would have consisted of a commercial company or government laboratory realizing it would be short of staff over the summer, about two days after the end of term, and then ringing around trying to find someone, anyone, who would sit on a boat in the rough North Sea for four weeks taking samples-preferably free of their previous meal. Now things are more organized and a number of companies plan well in advance to employ undergraduates over the summer. In the UK, for example, Fugro-GEOS

Simon Boxall (srb2@noc.soton.ac.uk) is Associate Fellow, University of Southampton, National Oceanography Centre, Southampton, UK. 


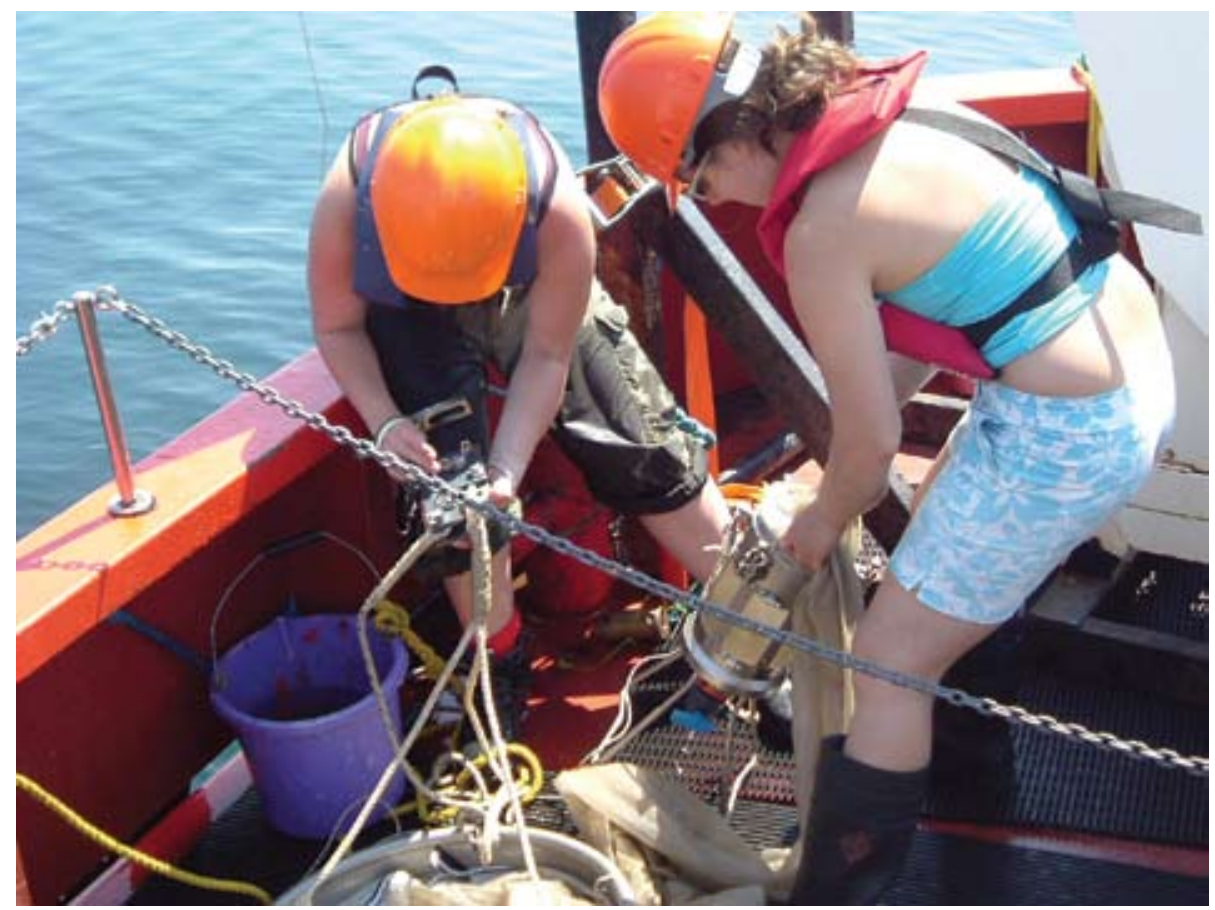

Figure 3. Two undergraduates sampling plankton in the English Channel while working for a commercial outfit.

runs a summer studentship program where they will employ two or three undergraduates for six to eight weeks. Candidates are interviewed and only the best are selected, but then a welllaid-out training program is arranged, and students get exposure to a number of aspects of the company, which can involve survey work on vessels abroad. At the National Oceanography Centre, students are also employed during the summer on both research and routine monitoring programs with extensive on-the-job training adding to their allimportant transferrable skills.

Students can search for their own funding, much of which comes from trusts. Nuffield, Shell (STEP), and Leverhulme all run schemes where an undergraduate can receive a bursary for support over the summer to carry out an individual research project. The student needs support from the academic department, in terms of supervision and laboratory facilities, but is otherwise financially independent. Leverhulme also support students from abroad for vocational study in the $\mathrm{UK}$, and most countries have equivalent organizations. I have had a number of students involved in all three schemes, and the work they have produced over the two to three summer months has been exceptionaland these students are not just from our own university.

So, what are the benefits for students working in oceanography over the summer rather than in local restaurants? The experience of working in the environment that hopefully they will be employed in for many years to come is obvious. Opportunities to witness what that environment is like outside of the comfort zone of the university often inspires them, and provides a focus for the successful completion of their
degrees-I have yet to have a student come back to me and announce a move into something completely different instead. For many, the contacts they make lead to $\mathrm{PhD}$ placements or jobs after graduation.

How about the benefits to the host or the employer? Working with young and enthusiastic minds can be very refreshing, and can lead you to view ideas differently. Employing young scientists usually provides very capable people to work with you and your team, as long as you remember they are still undergraduates and have as yet limited experiences. Few universities will want to recommend any but their best students so the chances of a problem student are very low. Shortterm positions such as these also give you a chance to "test drive" potential new employees. Getting the best staff these days seems to get harder, as does losing inefficient ones-many students end up working with the organizations that employed them during their vacation period(s).

The potential benefits of undergraduates working in their fields of study over the long vacation are clear, for both the students and the hosts. The time to act is now-hence, publishing this installment first. Students should be looking toward summer employment in December/ January, and potential hosts should be thinking about placements in the same period. But what are the benefits of spending a full year studying abroad as a formal part of a degree program? For that, you'll have to wait. In the meantime, I'm preparing my own "undergraduate" résumé for Canada 2009-why should my students have all the fun over the summer? 四 